\title{
Hypoplastic left heart syndrome: What's next?
}

\author{
Harold M. Burkhart, MD, ${ }^{a}$ Jess L. Thompson, MD, ${ }^{a}$ and Timothy J. Nelson, MD, $\mathrm{PhD}^{\mathrm{b}, \mathrm{c}, \mathrm{d}, \mathrm{e}}$
}

\footnotetext{
From the ${ }^{a}$ Division of Cardiovascular and Thoracic Surgery, University of Oklahoma Health Sciences Center, Oklahoma City, Okla; and ${ }^{\mathrm{b}}$ Division of General Internal Medicine, ${ }^{\mathrm{c}}$ Department of Molecular Pharmacology and Experimental Therapeutics, ${ }^{\mathrm{d}}$ Transplant Center, and ${ }^{\mathrm{e}}$ Center for Regenerative Medicine, Mayo Clinic, Rochester, Minn.

Disclosures: Authors have nothing to disclose with regard to commercial support.

Received for publication Dec 14, 2015; accepted for publication Dec 14, 2015; available ahead of print Jan 22, 2016.

Address for reprints: Harold M. Burkhart, MD, Division of Cardiovascular and Thoracic Surgery, University of Oklahoma Health Sciences Center, PO Box 26901, WP-2230, Oklahoma City, OK 73105 (E-mail: Harold-burkhart@ ouhsc.edu).

J Thorac Cardiovasc Surg 2016;151:909-10

$0022-5223 / \$ 36.00$

Copyright (C) 2016 by The American Association for Thoracic Surgery

http://dx.doi.org/10.1016/j.jtcvs.2015.12.032
}

During the past 4 decades, the field of congenital cardiac surgery has made remarkable strides in the care of patients with complex congenital cardiac anomalies. The care of neonates with hypoplastic left heart syndrome (HLHS) has received a great deal of attention with management strategies evolving and early surgical results improving. ${ }^{1}$ Despite the incredible progress that has been made in managing these complex patients, the 5-year transplantfree survival remains around $50 \%$. Poor cardiac function and pulmonary architecture are issues that result in a less-than-perfect Fontan patient contributing to this less-than-ideal survival.

In this issue of the Journal, the 2 largest single-center experiences with the hybrid approach for HLHS are presented. Both institutions champion the advantages of the hybrid approach; controlling pulmonary artery blood flow and systemic circulation while avoiding cardiopulmonary bypass and extensive cardiac reconstruction during the neonatal period. Yerebakan and colleagues ${ }^{2}$ present their 17-year surgical experience with 126 patients managed with a hybrid single-ventricle strategy. The overall surgical results are exceptional with low mortality reported at each stage. Galantowicz and Yates ${ }^{3}$ discuss their comprehensive experience with the comprehensive stage 2 procedure after a hybrid stage 1 procedure. By instituting protocols to help control the risk factors (eg, pulmonary artery thrombosis, emergent operation, and age) for the challenging comprehensive stage 2 procedure, they are able to significantly decrease mortality. These articles are significant in that they demonstrate the HLHS hybrid pathway can be expected to be very successful in the hands of experienced, high-volume centers.

Although the articles ${ }^{2,3}$ provide important insight to the successful management of these patients with a hybrid strategy, it is important to remember that there is clearly a learning curve, with very few centers reporting this caliber of results. Issues with appropriate pulmonary artery band tightening and ductal stent positioning are of continued

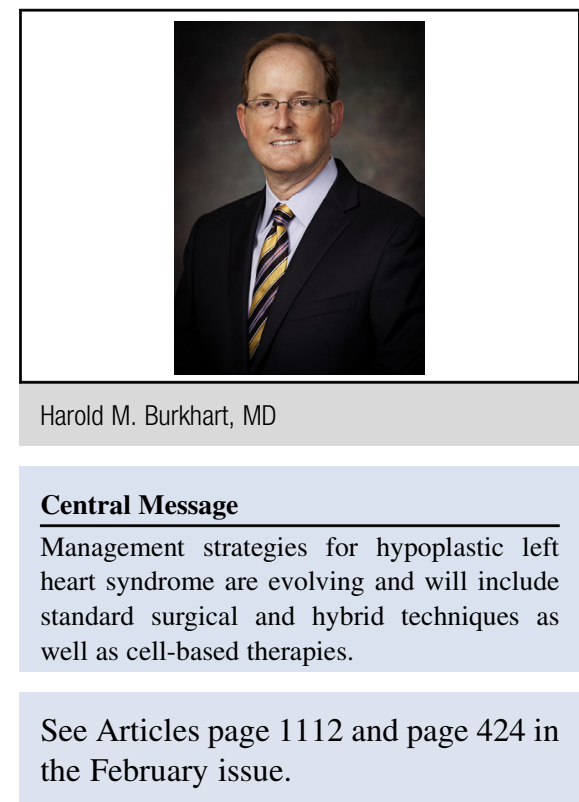

See Editorial Commentary page 1123.

concern-not to mention the occasional problem of retrograde aortic arch obstruction. In addition, having bands around the branch pulmonary arteries for months can create problems negatively influencing a patient's Fontan candidacy. After comprehensive stage 2 procedure, both groups report significant issues with pulmonary artery architecture necessitating further intervention.

Because innovation leads to innovation, it is clear that the hybrid strategy is evolving as well. In an effort to have the early advantages of the hybrid stage 1 procedure while avoiding the disadvantages of the comprehensive stage 2 procedure, some institutions are reporting the successful use of a rapid 2-stage Norwood procedure in selected or all patients with HLHS. ${ }^{4-6}$ This strategy involves bilateral pulmonary artery banding while using prostaglandins for ductal patency. After 2 to 3 weeks, after any concerning issues have resolved, a Norwood procedure is performed. Although this strategy was likely initially used as a salvage procedure to offer care to newborn infants deemed unfit for a Norwood procedure, the use of this approach has expanded. There are numerous benefits to the strategy of palliating before Norwood palliation. It offers a relatively quick technique to aid patients who present in cardiogenic shock while avoiding cardiopulmonary bypass and, hopefully, mechanical support. The same goes for those presenting with concerns of infection. In addition, it allows time to sort 
out any concerning extracardiac issues or syndromes. As these varying hybrid strategies evolve, 1 thing is evident: A surgeon will need to be familiar with all the options to successfully progress and improve surgical outcomes.

As surgical strategies evolve and result in a higher rate of HLHS survival, other therapies will have to be used to improve the long-term outlook. Regenerative strategies that include cell-based therapeutics offer a new adjunctive approach to augment surgical repair of HLHS. In contrast to the relatively quiescence of adult cardiac tissues, which retain only a $1 \%$ turnover rate annually, fetal myocardium retains a robust regenerative capacity that decreases in the first months to years of life. ${ }^{7-9}$ Notably, animal studies demonstrate a remarkable capacity of cardiac tissue to dramatically respond to injury within the first few postnatal days. This innate regenerative capacity is further supported by the observation that human cardiac progenitor cells decrease 10 -fold to adult levels within 2 to 4 weeks postnatal. In fact, pressure overload in the right ventricle in pediatric hearts results in a 3 -fold increase in cardiac stem cells and indicates that an adaptive response is present in youth. Therefore, the clinical application of regenerative strategies provides new avenues for therapeutic benefit. ${ }^{10,11}$

The role of cell-based therapies in HLHS has been significantly bolstered in 2015. The initial case reports suggested that children with heart failure might benefit from intracoronary bone marrow-derived mononuclear cell delivery; this included a child with HLHS. ${ }^{12-14}$ The first 1year follow-up for a pediatric cohort was published with dilated cardiomyopathy patients who received bone marrow stem cells. The patients showed significant improvement in left ventricle ejection fraction within 6 months that was stable for at least 12 months. ${ }^{15}$ The first clinical trial for HLHS using cell-based therapy was completed in Japan with a 3year follow-up on 7 patients. This study demonstrated the safety and feasibility of intracoronary infusion of cardiacderived autologous cells. The study also suggested a therapeutic benefit compared with a control group with sustained improvement in right ventricle ejection fraction after 36 months. $^{16}$ In addition to coronary infusions, $\mathrm{we}^{17}$ reported the first case of intramyocardial injections of autologous cells derived from umbilical cord blood for a patient with HLHS. This approach maintains the use of autologous cell types to avoid any potential alloantibody formation and aims to optimize the myocardial response to increased workloads at the time of stage II surgery. The goal of these studies should be to improve right ventricle performance and prevent subsequent Fontan failures by early intervention. Leveraging the technologies available today to augment cardiac function with low-cost and readily accessible tools should be a priority throughout the innovation process. Engaging payers into the process as early as possible with a focus on improved outcomes will further accelerate the development of these emerging cell-based regenerative technologies.

\section{References}

1. Iannettoni MD, Bove EL, Mosca RS, Lupinetti FM, Dorostkar PC, Ludmirsky A. Improving results with first stage palliation for hypoplastic left heart syndrome. J Thorac Cardiovasc Surg. 1994;107:934-40.

2. Yerebakan C, Valeske K, Elmontaser H, Yörüker U, Mueller M, Thul J, et al. Hybrid therapy for hypoplastic left heart syndrome: myth, alterntive, or standard? J Thorac Cardiovasc Surg. 2016;151:1112-23.

3. Galantowicz M, Yates A. Improved outcomes with the comprehensive stage 2 procedure after an initial hybrid stage 1. J Thorac Cardiovasc Surg. 2016;151:424-9.

4. Davies R, Radtke W, Bhat M, Baffa J, Woodford E, Pizarro C. Hybrid palliation for critical systemic outflow obstruction: neither rapid stage 1 Norwood nor comprehensive stage 2 mitigate consequences of early risk factors. J Thorac Cardiovasc Surg. 2015;149:182-93.

5. DiBardino D, Gomez-Arostegui J, Kemp A, Raviendran R, Hegde S, Devaney EJ, et al. Intermediate results of hybrid versus primary Norwood operation. Ann Thorac Surg. 2015;99:2141-9.

6. Ota N, Murata M, Tosaka Y, Ide Y, Tachi M, Ito H, et al. Is routine rapid-staged bilateral pulmonary artery banding before stage 1 Norwood a viable strategy? J Thorac Cardiovasc Surg. 2014;148:1519-25.

7. Bergmann O, Bhardwaj RD, Bernard S, Zdunek S, Barnabé-Heider F, Walsh S, et al. Evidence for cardiomyocyte renewal in humans. Science. 2009;324:98-102.

8. Amir G, Ma X, Reddy VM, Hanley FL, Reinhartz O, Ramamoorthy C, et al. Dynamics of human myocardial progenitor cell populations in the neonatal period. Ann Thorac Surg. 2008;86:1311-9.

9. Rupp S, Bauer J, von Gerlach S, Fichtlscherer S, Zeiher AM, Dimmeler S, et al. Pressure overload leads to an increase of cardiac resident stem cells. Basic Res Cardiol. 2012;107:252.

10. Selem SM, Kaushal S, Hare JM. Stem cell therapy for pediatric dilated cardiomyopathy. Curr Cardiol Rep. 2013;15:369.

11. Bernstein HS, Srivastava D. Stem cell therapy for cardiac disease. Pediatr Res. 2012; 71:491-9.

12. Rupp S, Jux C, Bönig H, Bauer J, Tonn T, Seifried E, et al. Intracoronary bone marrow cell application for terminal heart failure in children. Cardiol Young. 2012;22:558-63.

13. Rupp S, Bauer J, Tonn T, Schächinger V, Dimmeler S, Zeiher AM, et al. Intracoronary administration of autologous bone marrow-derived progenitor cells in a critically ill two-yr-old child with dilated cardiomyopathy. Pediatr Transpl. 2009;13:620-3.

14. Rupp S, Zeiher AM, Dimmeler S, Tonn T, Bauer J, Jux C, et al. A regenerative strategy for heart failure in hypoplastic left heart syndrome: intracoronary administration of autologous bone marrow-derived progenitor cells. J Heart Lung Transplant. 2010;29:574-7.

15. Bergmane I, Lacis A, Lubaua I, Jakobsons E, Erglis A. Follow-up of the patients after stem cell transplantation for pediatric dilated cardiomyopathy. Pediatr Transplant. 2013;17:266-70.

16. Tarui S, Ishigami S, Ousaka D, Kasahara S, Ohtsuki S, Sano S, et al. Transcoronary infusion of cardiac progenitor cells in hypoplastic left heart syndrome: three-year follow-up of the Transcoronary Infusion of Cardiac Progenitor Cells in Patients with Single-Ventricle Physiology (TICAP) trial. J Thorac Cardiovasc Surg. 2015;150:1198-208.

17. Burkhart H, Qureshi MY, Peral SC, O'Leary PW, Olson TM, Cetta F, et al. Regenerative therapy for hypoplastic left heart syndrome: first report of intraoperative intramyocardial injection of autologous umbilical-cord blood-derived cells. J Thorac Cardiovasc Surg. 2015; 149:e35-7. 